\title{
Comparative Study of Hypoglycemic Effects of Aqueous Extracts of Leaves and Fruits of Garden Egg (Solanum Melongena) In Alloxan Induced Diabetic Guinea Pigs
}

\author{
Akunneh Wariso Chris $\mathrm{C}^{1 *}$, Aduema Wadioni' ${ }^{2}$, Iheukwumere $\mathrm{CB}^{3}$ and Akunneh Wariso $\mathrm{Ngozi}^{4}$ \\ ${ }^{1}$ Department of Human Physiology, Faculty of Basic Medical Sciences, Abia State University, Nigeria
}

${ }^{2}$ Department of Human physiology, PAMO, University of Medical Sciences, Port Harcourt, Rivers State, Nigeria

${ }^{3}$ Department of Human Physiology,Abia State University, Nigeria

4Department of Ophthalmology, Abia State University Teaching Hospital, Nigeria

Submission: March 28, 2018; Published: July 18, 2018

*Corresponding author: Akunneh Wariso Chris, Department of Human Physiology, Faculty of Basic Medical sciences, Abia State University, Uturu, Nigeria, Tel: +2348069300842; Email: healthchris@yahoo.com

\begin{abstract}
The aim of this research work was to carry out a comparative study on the aqueous extracts of the leaves and fruits of Garden egg (Solanum melongena) using alloxan induced diabetic guinea pigs. Blood glucose level analysis was used as diabetic indices. Z-test was used in comparing the mean fasting blood glucose level of alloxan induced diabetic guinea pigs after administration of aqueous leaf extracts and that of the aqueous extracts of the fruits of Garden egg (Solanum melongena) against the negative control $(0.9 \% \mathrm{~N} / \mathrm{S}$ ) and positive control group (Glibenclamide solution).The results showed that there was a significant difference between the group that had oral administration of aqueous leaf extracts and the negative control group ( $\mathrm{p}<0.01$ ). No significant difference was seen between the group that had oral administration of aqueous fruit extracts of this plant and negative control which has no anti diabetic effect ( $p>0.05$ ).The positive control group (the group that had oral administration of hypoglycemic drug) showed $60 \%$ reduction of the mean fasting blood glucose level after administration of this hypoglycemic drug (Glibenclamide solution) while the group that had aqueous leaf extracts of Solanum melongena showed $40 \%$ reduction of mean fasting blood glucose level after its administration. The group that had oral administration of the aqueous fruit extracts and the negative control group showed no level of reduction of the mean fasting blood glucose level (0\%). This indicates that the aqueous leaf extract have hypoglycemic effects while aqueous fruit extract have no hypoglycaemic effect. However, there was also significant difference between the group that had aqueous leaf extracts and those that had aqueous fruits extracts of the same plant $(\mathrm{p}<0.01)$.Similarly, there was significant difference between the positive control group and those groups with aqueous leaf and fruit extracts but a higher significant difference was seen between this positive control group and the group with aqueous fruit extracts $(\mathrm{p}<0.01)$. Our finding also showed that in as much as the aqueous leaf extracts have hypoglycemic effects but cannot be compared with that of the hypoglycaemic drugs.
\end{abstract}

Keywords: Diabetic mellitus; Dietary aqueous extracts; Dietary aqueous fruits of Solanum melongenia and blood glucose

\section{Introduction}

There is two major tropical botanical flowering or dietary plants species in this family of solanaceae. These are solanum aethiopicumand Solanum melongena. However, in this study, Solanum melongena species was used. Solanum species are popularly known as Garden egg plants. These plants are made up of leaves, fruits, stems and roots. Many tribes or ethnic groups have different names, for instance, in igbo, it is called "Aghara" (Anara) or "Afufa", guata in Hausa, Anyara in Efik, "Nya" in Ibibio and Igbaaja in Yoruba. It can also be called bitter tomato. Aside its therapeutic benefits, these leaves and fruits are consumable. In herbal practice, these aqueous leaf extracts are extensively used in management of diabetes mellitus (Arazu and Okafor 2005). Antidiabetic efficacy of Solanum melongena was established by different researchers [1].Solanum Melongena may be used by patient suffering from raised intraocular pressure (glaucoma) and convergence insufficiency[2]. Aside its hypoglycemic effects, other health benefits of Solanum melongena are cardio 
protection, good source of dietary fiber for free bowel motion, enhancing good skin and hair, contains folate, magnesium, vitamin, especially vitamin $\mathrm{K}$ and $\mathrm{C}$, improves blood circulation and has been found to be useful in patients with heart diseases. Diabetes mellitus is a syndrome characterized by hyperglycemia and disturbances of carbohydrate, fat, and protein metabolism resulting from defects in insulin secretion, insulination or both Deficient insulin action is due to inadequate insulin production or peripheral resistance to insulin at one or more points in the complex pathways of hormone action[3]. Notwithstanding, the present study was therefore undertaken in an effort to further search for a better curative and safe agents for treatment and management of diabetes mellitus.

\section{Materials and Methods}

This species of Solanum melongena was fully identified and authenticated at the department of Botany (plant science) of University of Port Harcourt, Choba, Nigeria. These plants were also taken to Department of Crop Science Technology, School of Agriculture and Agriculture Technology, Federal university of Technology, Owerri, Nigeria. A voucher specimen was deposited at the Herbarium for reference purpose.

\section{Preparation of extracts}

Fresh leaves of Solanum melongena were dried for 5 minutes in an oven at temperature 400c to stop enzymatic activity and air dried to constant weight and milled to fine powder and the subjected aqueous extraction was used for administration. Aqueous extract of the garden egg fruit was obtained by milling or grinding about $150 \mathrm{~g}$ of the fruits with $100 \mathrm{mls}$ of after washing and then aqueous extraction was collected. Significant degradation in free radical savaging activities in medicinal plants occurs in samples maintained at temperatures in excess of $400 \mathrm{c}$.

\section{Experimental animals}

A total of 24 guinea pigs irrespective of sexes with average weight of $300 \mathrm{~g}$ were grouped into 4 groups and housed in different cages at room temperature. They were fed with water and elephant grasses. These groups were group A to D with each group containing 8 guinea pigs.

Group A was the negative control group that was given $0.9 \%$
N/S (physiological solution).

Group B was the positive control group that was given Glibenclamide solution.

Group $\mathrm{C}$ was the group that was given aqueous leaf extracts of Solanum melongena.

Group D was the group that was given aqueous fruit (garden egg) extract of Solanum melongena.

\section{Substance administration}

Guinea pigs of both sexes with average weight of $300 \mathrm{~g}$ were used in this study. Each guinea pig was made diabetic using a single dose of $200 \mathrm{mg} / \mathrm{kg}$ body weight of Alloxan administered intraperitoneally with $2 \mathrm{ml}$ syringe. (During the preliminary test, single dose alloxan induction intraperitoneally at concentration of $100 \mathrm{mg} / \mathrm{kg}$ and $150 \mathrm{mg} / \mathrm{kg}$ body weight revealed differential increases in mean fasting blood glucose level less than $1.00 \mathrm{mmol} / \mathrm{L}$ ). The negative control group (Group A) received $2.0 \mathrm{ml} / \mathrm{kg}$ body weight of normal saline while the positive control group (Group B) had oral administration of $0.25 \mathrm{mg} /$ day of glibenclamide (oral hypoglycemic drug). The test groups $\mathrm{C}$ and D received $0.5 \mathrm{~g} / \mathrm{kg}$ body weight of the aqueous leaf extracts of Solanum melongena and aqueous fruit extracts of the same plant respectively orally through canular.

\section{Determination of fasting blood glucose level}

Using a $2 \mathrm{ml}$ syringe, a 12 hourly fasting blood glucose samples were collected from the ears of the experimental guinea pigs by venepuncture. Pretreatment samples were used to estimate the physiological baseline values of the fasting blood glucose level. Blood samples were spotted on ultra easy one touch glucometer (Johnson and johnso company UK) strip (code No.9) and the values were recorded appropriately using the glucose monitor.

\section{Statistical analysis}

The multivariate analytical statistical package for social science (SPSS), version 15 was used for the analysis. The results were further subjected to Z-test and ANOVA analysis. However, the percentage differences in the test groups were also compared with control, $\mathrm{P}<0.01$ or $\mathrm{P}<0.05$ was taken as significant difference.

Table1: Mean fasting blood glucose before and after alloxan induction and after substance administration.

\begin{tabular}{|c|c|c|c|c|}
\hline Substances & $\begin{array}{l}\text { Fasting Blood Glucose } \\
\text { before Alloxan Induction } \\
\text { of Diabetic (mmol/L) }\end{array}$ & $\begin{array}{l}\text { Fasting Blood Glucose after } \\
\text { Alloxan Indiction of Diabetic } \\
(\mathrm{mmol} / \mathrm{L})\end{array}$ & $\begin{array}{l}\text { Fasting Blood Glucose } \\
\text { After Substance } \\
\text { Administration } \\
\text { (mmol/L) }\end{array}$ & $\begin{array}{c}\text { Percentage } \\
\text { Reduction (\%) }\end{array}$ \\
\hline $0.9 \% \mathrm{~N} / \mathrm{S}(\mathrm{n}=8+$ & $4.98 \pm 0.08(4.88-5.10)$ & $6.97 \pm 0.04(6.9-7.0)$ & $7.05 \pm 0.05(7.0-7.10)$ & 0 \\
\hline \multirow{2}{*}{ Glibenclamide solution $(n=8)$} & $5.02 \pm 0.12$ & $7.0 \pm 0.12$ & $5.02 \pm 0.12$ & \multirow{2}{*}{60} \\
\hline & $(4.90-5.13)$ & $(6.8-7.1)$ & $(4.83-5.10)$ & \\
\hline \multirow{2}{*}{$\begin{array}{l}\text { Aqueous leaf extract of } \\
\text { solanum melongena }\end{array}$} & $4.47 \pm 0.57$ & $7.0 \pm 0.05$ & $6.02 \pm 0.25$ & \multirow{2}{*}{40} \\
\hline & $(4.88-5.03)$ & $7.0-7.1)$ & $(5.73-6.40)$ & \\
\hline \multirow{2}{*}{$\begin{array}{l}\text { Aqueous fruit (garden egg) } \\
\text { extracts of solanum melongena }\end{array}$} & $5.03 \pm 0.09$ & $6.96 \pm 0.67$ & $6.85 \pm 0.05$ & \multirow{2}{*}{0} \\
\hline & $(4.90-5.13)$ & $(6.9-7.0)$ & $(6.8-6.90)$ & \\
\hline
\end{tabular}




\section{Current Research in Diabetes \& Obesity Journal}

\section{Results}

The results obtained are shown in the Table1.

\section{Discussion}

It is known that diabetes mellitus is one of the commonest tropical endocrine or metabolic diseases [4]. The incidence and prevalence of diabetes mellitus is growing rapidly worldwide. For example, it is estimated that over 135 million people worldwide are suffering from the most common form of type II (Harvey and Champe2006). It is also estimated that about 10 million Nigerians are diabetic.Nevertheless, having known these, it is therefore important that development and study of alternative safe ant diabetic regimen especially in plants should be encouraged instead of oral hypoglycemic and insulin formulation. It will also help in abating undesired side effects of these agents such as erectile dysfunction etc. This study was to compare the hypoglycemic effects of aqueous leaf and aqueous fruit extracts of Solanum melongena using alloxan induced diabetic guinea pigs. The mean fasting blood glucose level in alloxan induced diabetic guinea pigs for two weeks with administration of these extracts are compared with oral hypoglycemic drug (glibenclamide) as the positive control group and with the physiological solution $(0.9 \% \mathrm{~N} / \mathrm{S})$ as the negative control group.

The Table 1above revealed that the oral hypoglycemic drug (glibenclamide) had $60 \%$ reduction in mean fasting blood glucose after administration while the aqueous leaf extracts of Solanum melongena had $40 \%$ reduction. The aqueous fruit extracts of this plant had no level of reduction of the mean fasting blood glucose level. Similarly, using ANOVA or z-test, the aqueous leaf extracts of this plant had $40 \%$ reduction of mean fasting blood glucose level after administration also showed significant difference with that of the oral hypoglycemic drug $(\mathrm{p}<0.05)$. This means that the aqueous leaf extracts possess some level hypoglycemic effects but not as high as the hypoglycemic drug. A higher significant difference was seen with the mean fasting blood glucose level after administration of glibenclamide and aqueous fruit extracts of the plant $(\mathrm{p}<0.01)$. However, administration of both the physiological solution $(0.9 \% \mathrm{~N} / \mathrm{S})$ and the aqueous fruit extracts of this plant in their respective groups showed no level of reduction in the mean fasting blood glucose level after administration. There is also no significant difference between the mean fasting blood glucose level after administration of $0.9 \% \mathrm{~N} / \mathrm{S}$ (negative control group) and after administration of aqueous fruit extracts ( $p>0.05$ ). This showed that the aqueous fruit extracts of this plant possess no hypoglycemic effect. Furthermore, significant difference was also seen between the mean fasting blood glucose level of the test group after administration of both extracts $(p<0.01)[5-15]$.

\section{Conclusion/Recommendation}

The aqueous leaf extracts of Solanum melongena possess some level hypoglycemic effects but not as high as the hypoglycemic drug. Whereas the aqueous fruit extracts of this plant in their respective groups showed no level of reduction in the mean fasting blood glucose level after administration. One may therefore recommend that further studies should be done as to ascertain its mechanism of action. In this case, the study should be related to absorption of glucose in the intestine, insulin resistance or increase insulin release in the body.

\section{Acknowledgement}

We wish to thank Dr. Wadioni A, Dr.Iheukwumere and Akunneh-Wariso Ngozi for their various contributions to the success of this research work.

\section{References}

1. Nwafor A, Akunneh C, Ojeka S, Ogbu A, Emmanuuel O (2013) Antidiabetic efficacy of dietary vegetable mixtures in alloxan induced diabetic guinea pigs. American Journal of Pharmacy and Health Research.

2. Igwe SA, Akunyili DN, Ogbogu C (2003) Ogbogu effects of solanum melongna (garden egg leaf) on visual functions of visually active igbos in Nigeria. J Ethnopharmacol 86(2-3): 135-138.

3. Falase AO, Akinkugbe 00 (2006) Compendium of clinical medicine 6(3): 313-317.

4. Adeluyibi A (1980) Companion to clinical medicine in the tropics 8: 160-165.

5. Chike CP, Georgewill OA, Nnochi (2006) CU effects of aqueous leaf extracts of vernonia amygdalins on blood glucose concentration of alloxan induced diabetic albino wister rats. Journal of Applied Zoology and Environmental Biology 8: 44-47.

6. Iwuji SC, Nwafor A, Chike PR, Iwuji NG, Nwaokoro JC (2013) Interactive effect of combined aqueous leaf extracts of occimum gratissinum and vernomia amygdalina on fasting blood glucose in rabbits. American Journal of Pharmacy Tech Res 3(5): 1-11.

7. Lenz S (2008) The mechanism of alloxan and sheptozotocin induced diabetes. Diabetolgia 51(2): 216-226.

8. Lenz S, Panten U (1998) History and mechanism of action. Diabetologia 31(6): 337-342.

9. Malriya N, Janin S, Malriya S (2010) Antidiabetic potentials of medicinal plants. Acta Pol Pharm 67(2): 113-118.

10. Modak M, Dixit P, Londhe J, Ghaskadbi S, Devasageyam T (2007) India herbs and herbal drugs used for treatment of diabetes. J Clin Brochem Nutr 40(3): 163-173.

11. Okafor JC (2003) Journal on predictive value of plant: taxanomy in ethno-medicine, pp. 20-26.

12. Shaw JE, Sicree RA, Zimmet PZ (2010) Global estimates of the prevalence of diabetes. Diabetes Res Clin Pract 87(1): 4-14.

13. Stuart R: Alloxantin dehydrates tipson organic synthesis coll 33: 3.

14. (2009) This day newspaper 14(5036): 33-34.

15. (2005) WHO national policy on traditional medicine and regulation of herbal medicine: report of a who global survey. 
(C) C. This work is licensed under Creative

BY DOI: 10.19080/CRDOJ.2018.08.555728
Your next submission with Juniper Publishers will reach you the below assets

- Quality Editorial service

- Swift Peer Review

- Reprints availability

- E-prints Service

- Manuscript Podcast for convenient understanding

- Global attainment for your research

- Manuscript accessibility in different formats

( Pdf, E-pub, Full Text, Audio)

- Unceasing customer service

Track the below URL for one-step submission https://juniperpublishers.com/online-submission.php 